\title{
REFORMASI HUKUM TATA NEGARA MELALUI AMANDEMEN KONSTITUSI (KRITIK TERHADAP PELAKSANAAN OTONOMI DAERAH DI INDONESIA PASCA REFORMASI)
}

\author{
Indra Fatwa \\ Universitas Muhammadiyah Riau, Indonesia, indrafatwa@umri.ac.id
}

\begin{abstract}
The purpose of this study was to find out the problems of the practice of regional autonomy in postReformation Indonesia. The research method used is a normative legal method with a descriptive analysis approach. The results of the study show that the practice of regional autonomy in postReformation Indonesia is still constrained in its implementation. This can be seen from the various laws and regulations derived from the 1945 Constitution of the Republic of Indonesia which still put forward a centralistic spirit. The conclusion of this research is that it is necessary to reform the law from derivative products of the constitution which regulates the implementation of regional autonomy. This can be started by making amendments to the Constitution.
\end{abstract}

Keywords: Regional Autonomy, Amendments, Constitution.

\begin{abstract}
Abstrak
Tujuan Penelitian ini adalah untuk mengetahui Problematika Praktik Otonomi Daerah di Indonesia pasca Reformasi. Metode penelitian yang digunakan adalah metode hukum normatif dengan pendekatan deskriptif analisis. Hasil penelitian menunjukkan bahwa praktik otonomi daerah di Indoensia pasca Reformasi masih terkendala dalam pelaksanaanya. Hal ini terlihat dari berbagai peraturan perundang-undangan turunan dari UUD NRI 1945 yang masih mengedepankan semangat sentralistik. Kesimpulan dari penelitian tersebut adalah perlu untuk dilakukannya pembaharuan hukum dari produk turunan konstitusi yang mengatur mengenai pelaksanaan otonomi daerah. Hal ini dapat dimulai dengan melakukan amandemen Konstitusi.
\end{abstract}

Kata Kunci: Otonomi Daerah, Amandemen, Konstitusi.

\section{Pendahuluan}

Konstitusi suatu negara pada hakekatnya merupakan hukum dasar tertinggi yang memuat hal-hal mengenai penyelenggaraan negara, karenanya suatu konstitusi harus memiliki sifat yang lebih stabil dari pada produk hukum lainnya. Terlebih lagi jika jiwa dan semangat pelaksanaan penyelenggaraan negara juga diatur dalam konstitusi sehingga 
perubahan suatu konstitusi dapat

membawa perubahan yang besar terhadap

sistem penyelenggaraan Negara. Bisa jadi

suatu negara yang demokratis berubah

menjadi otoriter karena terjadi perubahan dalam konstitusinya. ${ }^{1}$

Reformasi sistem ketatanegaraan Indonesia ditandai dengan lengsernya pemerintahan Orde Baru yang telah berkuasa selama 32 tahun $^{2}$ yang diinisiasi melalui pergerakan mahasiswa dari seluruh Indonesia yang “mengepung” Jakarta pada Mei tahun 1998. Salah satu tuntutan terbesar dari gerakan yang digalang oleh sekelompok orang yang juga menyebut dirinya sebagai kalangan reformis ${ }^{3}$ adalah, dilakukannya amandemen terhadap

${ }^{1}$ Despan Heryansyah dan Harry Setya

Nugraha, Relevansi Putusan Uji Materi oleh Mahkamah Konstitusi terhadap Sistem Checks and Balances dalam Pembentukan Undang-Undang, Undang: Jurnal Hukum, Volume 2, Nomor 2, hlm 370

${ }^{2}$ Meskipun sesungguhnya periode resmi penguasa Orde Baru yaitu Soeharto baru menjadi Pejabat Presiden pada 1967 dan menjadi Presiden defenitif pada 1968, namun secara politik telah disepakati bahwa awal kepemimpinan Soeharto dihitung sejak dikeluarkannya Surat Perintah Sebelas Maret (Supersemar) pada 1966.

${ }^{3}$ Sekelompok kalangan yang ketika itu menjadi motor penggerak masyarakat dan mahasiswa khususnya di seluruh Indonesia, untuk melakukan gerakan reformasi yang dipimpin oleh Amien Rais, konstitusi kita dalam hal ini adalah amandemen terhadap Undang Undang Dasar 1945 (UUD 1945). Amandemen ini merupakan sebuah keniscayaan yang tak dapat dibendung lagi sebagai konsekuensi dari gerakan demokrasi pada masa itu. ${ }^{4}$

Salah satu buah dari hasil amandemen tersebut adalah lahirnya sebuah sistem pemerintahan yang menghendaki pelimpahan wewenang dari pemerintah pusat kepada pemerintah daerah untuk mengatur dan mengurusi urusan rumah tangganya sendiri, namun tentu tetap berada di dalam pattern negara kesatuan. Tidak heran tuntutan tersebut menjadi salah satu rekomendasi utama yang diajukan ketika masa amandemen konstitusi, mengingat ketika rezim orde baru berkuasa hubungan pemerintaha pusat dan daerah berjalan sangat tidak harmonis. Pemerintah pusat dalam hal ini adalah Jakarta, ketika itu hanya menjadikan daerah terutama daerah-daerah yang kaya

\footnotetext{
${ }^{4}$ Moh. Mahfud MD, Konstitusi dan Hukum dalam Kontroversi Isu, Jakarta, Rajawali Press, 2012, hlm 114
} 
akan sumber daya alam sebagai "mesin ATM" tanpa memperdulikan bagi hasil yang sepadan buat pemerintah daerah. Hasilnya adalah, banyak daerah-daerah di luar pulau jawa mengalami ketertinggalan yang sangat jauh di berbagai bidang dikarenakan sistem bagi hasil yang tidak adil dan pemerintahan yang terlalu sentralistik. Semangat ini yang kemudian direpresentasikan dengan lahirnya ketentuan bagi daerah untuk menjalankan otonomi daerah seluas-luasnya melalui amandemen UUD $1945 .^{5}$

Seiring berjalannya waktu, pasca reformasi 1998 dan amandemen UUD 1945 yang dilakukan sebagai konsekuensi dari reformasi. Eksistensi otonomi daerah di Indonesia belum dirasakan sepenuhnya berhasil atau bahkan memuaskan, masih banyak kekurangan dan kelemahan dari pelaksanaan otonomi daerah di dalam negara kesatuan ini. Hal ini di perkuat dengan pengetatan peraturan perundang-

${ }^{5}$ Indra Fatwa, Gagasan Kawasan Ekonomi Khusus Dumai Berbasis Industri Hilir Kelapa Sawit, Universitas Islam Indonesia, Yogyakarta, 2017, hlm 5 undangan sebagai peraturan pelaksana otonomi daerah yang menjauhkan dari semangat otonomi daerah seluas-luasnya sebagaimana yang dicita-citakan ketika reformasi. Sebagai contoh, UndangUndang Perimbangan Keuangan Pusat dan Daerah No. 33 Tahun 2004 yang belum memberikan manfaat berarti bagi daerah malah cenderung dirasakan tidak adil bagi daerah. Yang terbaru adalah UndangUndang No. 11 Tahun 2020 Tentang Cipta Kerja, yang mereduksi begitu banyak kewenangan Pemerintah Daerah dalam berbagai hal. Hal ini tentu tidak sejalan dengan semangat otonomi daerah pasca reformasi.

\section{Rumusan Masalah}

Berdasarkan uraian dalam latar belakang masalah di atas, maka Penulis menarik rumusan masalah yaitu. Pertama, apakah problematika otonomi daerah di Indonesia pasca reformasi?

\section{Tujuan Penelitian}


Penelitian ini bertujuan untuk menganalisis berdasarkan peraturan perundang-undangan yang ada apakah problematika otonomi daerah di Indonesia pasca Reformasi. Serta bagaimana solusi perbaikan yang ditawarkan.

\section{Metode Penelitian}

Metode penelitian yang digunakan dalam penelitian ini adalah yuridis normatif, yaitu dengan memperhatikan ketentuan perundang-undangan yang mengatur tentang praktik otonomi daerah di Indonesia menurut UUDNRI 1945 dan Peraturan Perundang-Undangan dibawahnya.

Pengumpulan bahan hukum dilakukan dengan studi pustaka yakni melalui pengkajian terhadap peraturan perundang-undangan dan berbagai pustaka yang relevan dengan objek penelitian. Dalam penelitian ini, data yang terkumpul dianalisis secara dekriptif kualitatif yang dipraktekkan melalui tiga alur kegiatan, yakni reduksi bahan hukum, penyajian bahan hukum, dan penarikan kesimpulan. ${ }^{6}$

\section{Hasil Penelitian dan Pembahasan}

\section{Landasan Teori dan Filosofis}

Konstitusi kita yang tertuang dalam UUD 1945 BAB I tentang bentuk dan kedaulatan Pasal 1 ayat (1), telah secara eksplisit menyebutkan bahwasanya bentuk pemerintahan Negara Indonesia adalah negara kesatuan yang berbentuk republik. Kemudian di Pasal 37 ayat (5) lebih lanjut dikatakan, Negara Indonesia akan tetap berbentuk Negara Kesatuan selamanya, kecuali Majelis Permusyawaratan Rakyat mengubah kembali ketentuan Pasal 37 ayat (5) tersebut. ${ }^{7}$ Namun di Pasal lainnya, konstitusi kita juga memberikan peluang untuk terselenggaranya sebuah pemerintahan yang "berbau" federal. Hal ini termaktub dalam Pasal 18 UUDNRI

\footnotetext{
${ }^{6}$ Indra Fatwa, Putusan Mahkamah
} Konstitusi Yang Bersifat Mengatur (Positive Legislature) Dalam Upaya Menghadirkan Keadilan Substantif, Jurnal Equitable, Volume 5, Nomor 2, April 2020, hlm 8

${ }^{7}$ Jimly Asshiddiqie, Konstitusi dan Konstitualisme Indonesia, Sinar Grafika, Jakarta, 2011, hlm 211 
1945 tentang pemerintahan daerah, yang

salah satu ketentuannya mengatakan

bahwa Negara Kesatuan Republik

Indonesia mengakui dan menghormati satuan-satuan pemerintahan daerah yang bersifat khusus atau bersifat istimewa yang diatur dengan undang-undang. ${ }^{8}$

Semangat otonomi daerah juga tercermin dalam konstitusi hasil amandemen setelah dikehendakinya pelimpahan kewenangan dan kekuasaan yang dari pemerintah pusat ke pemerintah daerah, sebagaimana ketentuan di dalam Pasal 18 ayat (2) yang mengatakan bahwa pemerintahan daerah provinsi, daerah kabupaten, dan kota mengatur dan mengurus sendiri urusan pemerintahan menurut asas otonomi dan tugas pembantuan.

Negara kesatuan adalah negara berdaulat yang diselenggarakan sebagai satu kesatuan tunggal, dimana pemerintah

\footnotetext{
${ }^{8}$ Wasisto Raharjo Jati, Inkonsistensi Paradigma Otonomi Daerah di Indonesia: Dilema Sentralisasi atau Desentralisasi, Jurnal Konstitusi, Volume 9, Nomor 4, Desember 2012, hlm 761
}

pusat adalah yang tertinggi dan satuansatuan subnasionalnya hanya menjalankan kekuasaan-kekuasaan yang dipilih oleh pemerintah pusat untuk didelegasikan. Bentuk pemerintahan kesatuan inilah yang banyak diterapkan negara di dunia. Selanjutnya yang dimaksud dengan Negara Kesatuan adalah, negara yang tidak terbagi atas beberapa negara bagian melainkan terdiri atas satu negara saja, sehingga ungkapan "negara dalam negara" tidak berlaku di dalam Negara Kesatuan. Oleh karena itu, di dalam Negara Kesatuan dianut dua asas yang sangat mempengaruhi keberlangsungannya pemerintahan. Asas tersebut adalah:

1. Asas sentralisasi, yaitu asas yang menghendaki segala kekuasaan serta urusan pemerintahan itu milik pemerintah pusat;

2. Asas konsentrasi, yaitu asas yang menghendaki bahwa segala kekuasaan serta urusan pemerintahan pusat dilaksanakan sendiri oleh pemerintah 
pusat, baik yang ada di pusat maupun daerah. $^{9}$

Negara Kesatuan dapat dibedakan dalam dua bentuk: (1) Negara Kesatuan dengan sistem sentralisasi; (2) Negara Kesatuan dengan sistem desentralisasi. Dalam negara kesatuan dengan sistem sentralisasi, segala sesuatu dalam negara langsung diatur dan diurus oleh pemerintah pusat, dan daerah-daerah tinggal melaksanakan segala apa yang telah diinstruksikan oleh pemerintah pusat. Sedangkan dalam negara kesatuan dengan sistem desentralisasi, kepada daerahdaerah diberikan kesempatan dan kekuasaan untuk mengatur dan mengurus urusan rumah tangganya sendiri (otonomi daerah) yang dinamakan dengan daerah otonom. ${ }^{10}$ Indonesia dewasa ini khususnya pasca reformasi lebih cenderung kepada penerapan sistem Negara Kesatuan dengan sistem desentralisasi, hal ini merupakan

\footnotetext{
${ }^{9}$ Soehino, Ilmu Negara, Liberti, Yogyakarta, 2005, hlm 224

${ }^{10}$ Ni'matul Huda, Desentralisasi Asimetris Dalam NKRI Kajian Terhadap Daerah Istimewa, Daerah Khusus dan Otonomi Khusus, Nusa Media, Bandung, 2014, hlm 2
}

salah satu buah yang dapat dipetik dari runtuhnya rezim orde baru.

$$
\text { Desentralisasi adalah asas }
$$
penyelenggaraan pemerintahan yang dipertentangkan dengan sentralisasi.

Desentralisasi menghasilkan pemerintahan lokal (local government), di sana terjadi “... a "superior" government - one encompassing a large jurisdiction - one encompassing a smaller jurisdiction - that is assumed to have some degree of authonomy." Adanya pembagian kewenangan serta tersedianya ruang gerak yang memadai untuk memaknai kewenangan yang diberikan kepada unit pemerintahan yang lebih rendah (pemerintah lokal), merupakan perbedaan terpenting antara konsep desentralisasi dan sentralisasi. Namun perbedaan konsep yang jelas ini menjadi remang-remang tatkala ditetapkan dalam dinamika pemerintahan yang sebenarnya. ${ }^{11}$ 
2. Kritik Terhadap Pelaksanaan

\section{Otonomi Daerah di Indonesia}

Setelah UUD 1945 diubah jelas dirasakan bahwa kran demokrasi mulai terasa terbuka dan mengalir begitu deras. Perubahan itu sendiri sesungguhnya merupakan sebuah kemajuan bagi kehidupan berbangsa dan bernegara di Indonesia, yang mana di era orde baru demokrasi dianggap sebagai barang haram yang jika di takar mustahil untuk dilaksanakan. Sekarang setelah UUD 1945 diubah, semua orang dapat mempersoalkan UUD, sekarang orang boleh saja mengusulkan agar UUD dirubah, atau semua orang dapat mengusulkan agar kembali lagi pada UUD yang asli. Semua ini dapat dilakukan tanpa harus khawatir dan takut ditangkap. Hal ini merupakan kemajuan besar dalam demokrasi kita.

Amandemen ini tentunya juga berdampak pada perkembangan hukum tata negara yang ada di Indonesia, diantaranya yang sangat menonjol dan tampak semakin baik adalah munculnya mekanisme checks and balances secara lebih proporsional di dalam sistem ketatanegaraan kita, pengujian peraturan perundang-undangan sesuai dengan perjenjangannya sekarang juga berjalan semakin baik dengan lahirnya Mahkamah Konstitusi sebagai lembaga penguji UU terhadap UUD 1945, penguatan fungsi legislasi DPR yang berdampak pada peningkatan produktifitas dalam pembuatan UU, dan pelimpahan beberapa kewenangan pusat kepada daerah yang direpresentasikan dengan pelaksanaan otonomi daerah yang seluas-luasnya. ${ }^{12}$

$$
\text { Aliran kran demokrasi yang begitu }
$$
deras juga terasa sampai ke daerah-daerah di seluruh Indonesia, hal ini di tunjukkan dengan mulai membaiknya hubungan antara pemerintah pusat dan pemerintah daerah pasca diberlakukannya otonomi daerah yang seluas-luasnya. Otonomi daerah yang diartikan sebagai pelimpahan beberapa kewenangan pusat ke daerah dan kewenangan daerah untuk mengurusi

\footnotetext{
${ }^{12}$ Ni"matul Huda, Otonomi Daerah, Pustaka Pelajar, Yogyakarta, 2005, hlm 34
} 
urusan rumah tangganya sendiri sebagaimana yang diamanatkan dalam UUD 1945, telah sedikit meredam tensi politik di daerah yang selama era orde baru merasa di anak tirikan oleh Jakarta dengan hanya menjadikan daerah sebagai "mesin ATM" semata. Bahkan tidak sedikit diantara daerah-daerah tersebut yang sudah membuat ancang-ancang untuk keluar dari NKRI. Sebut saja Gerakan Aceh Merdeka (GAM), Republik Maluku Selatan (RMS), Operasi Papua Merdeka (OPM), Gerakan Riau Merdeka, dan sebagainya yang ketika itu gencar terjadi di beberapa daerah.

Kini setelah 18 (delapan belas) tahun kita menggenggam demokrasi pasca reformasi yang dialami negri ini pada tahun 1998, apabila kita sedikit mengevaluasi jalannya otonomi daerah di Indonesia masih banyak dirasakan kekurangan dan tuntutan yang belum sepenuhnya terealisasi sebagaimana semangat dan cita-cita ketika dulu menjatuhkan rezim orde baru. Masih banyak daerah yang merasakan ketertinggalan yang sangat jauh di berbagai bidang jika dibandingkan dengan kondisi yang ada di pulau Jawa, tidak hanya masalah ketertinggalan daerah yang belum terselesaikan, permasalahan kecemburuan daerah mengenai dana bagi hasil $(\mathrm{DBH})$ atas sumber daya alam yang dimiliki juga masih banyak dijumpai dan dikeluhkan oleh daerah. Keluhan-keluhan ini semakin terasa dengan pengetatan aturan pelaksana yaitu UU Otonomi Daerah No. 34 Tahun 2004 dan UU Perimbangan Keuangan Pusat dan Daerah No. 33 Tahun 2004 yang dibuat oleh pemerintah pusat, inilah yang kemudian membuat kesan pemerintah pusat masih berhasrat besar untuk mencampuri kepentingan daerah dengan mengabaikan semangat otonomi daerah yang sesungguhnya.

\section{Dilema Desentralisasi dan}

\section{Sentralisasi}

Salah satu hasil reformasi di bidang hukum tata negara adalah adanya perbaikan hubungan antara pusat dan 
daerah. Pemerintah Daerah melaksanakan wewenangnya secara lebih bebas sesuai dengan aspirasi masyarakat. Walaupun Undang-Undang Nomor 32 Tahun 2004 yang kemudian telah direvisi berlaku umum untuk semua daerah, namun tetap terbuka adanya perlakuan khusus bagi suatu daerah. Adanya perlakuan khusus itu sangat dimungkikan untuk menjawab kondisi khusus yang dihadapi oleh suatu daerah dalam hubungannya dengan Pemerintah Pusat. Hal ini sebagaimana tercermin dalam ketentuan konstitusi Pasal 18 UUD 1945 tentang pemerintahan daerah, yang salah satu ketentuannya mengatakan bahwa Negara Kesatuan Republik Indonesia mengakui dan menghormati satuan-satuan pemerintahan daerah yang bersifat khusus atau bersifat istimewa yang diatur dengan undangundang.

Pelaksanaan otonomi daerah yang seluas-luasnya di Indonesia sebagai konsekuensi dari reformasi, ternyata dirasakan belum sepenuhnya memenuhi apa yang menjadi kehendak dan tujuan dari masyarakat di daerah. Pada perkembangannya pasca runtuhnya rezim Orde Baru, banyak daerah yang menuntut untuk ditetapkan sebagai daerah Otonomi Khusus, yaitu satuan-satuan daerah yang diatur oleh undang-undang mengenai sistem satuan pemerintahan Otonomi Daerah yang mempunyai kekhususan dibanding dengan daerah lain. Dalam perkembangannya, selama Indonesia merdeka, baru empat daerah yang mendapatkan status tersebut. Daerah tersebut adalah Provinsi Daerah Khusus Ibu Kota Jakarta, Provinsi Daerah Istimewa Yogyakarta, Provinsi Daerah Istimewa Nangroe Aceh Darussalam, dan Provinsi Papua.

Banyaknya tuntutan akan penetapan daerahnya sebagai daerah Otonomi Khusus (Otsus) salah satunya datang dari bumi Lancang Kuning, Riau. Bukan tanpa alasan yang kuat rakyat Riau menuntut akan penetapan Otsus di daerahnya, sebagai salah satu daerah yang kaya 
dengan sumber daya alam di Indonesia, Riau telah bertahun-tahun merasakan ketidakadilan yang bersumber dari Jakarta. Rakyat Riau tidak dapat menikmati sepenuhnya hasil dari kekayaan alamnya sendiri, Dana Bagi Hasil (DBH) yang diterima pemerintah Riau tidak sepadan dengan apa yang telah dihasilkan. Jakarta masih setengah hati memberikan hak otonomi yang luas kepada daerah untuk mengatur dan mengurusi urusan rumahtangganya sendiri.

Otonomi khusus tentu saja berbeda dengan otonomi dalam artian umum. Otonomi khusus diadakan karena dengan pemberlakuan otonomi (umum) tidak akan sanggup meredam kekecewaan suatu masyarakat atau memperbaiki kekeliruan dan kesalahan masa lalu. Tetapi tidak sesederhana pemikiran awam, dalam bentuk format yang bagaimana otonomi yang diinginkan masyarakat Riau. Berdasarkan hal di atas adalah wajar bila perincian format otonomi khusus bagi Provinsi Riau harus tetap memperhatikan konsep negara kesatuan jika wacana pengajuan Otsus itu benar-benar terlaksana. Namun yang harus diperhatikan adalah konsep negara kesatuan yang mana yang hendak dianut, versi orde baru yang sentralistis atau versi yang dianut oleh sebuah republik yang sangat sentralistis namun bersedia untuk melonggarkan diri. ${ }^{13}$

Terlepas dari itu semua, otonomi daerah semestinya membawa angin segar bagi semua daerah di Indonesia. Tapi kenyataannya otonomi daerah justru mendatangkan dilema terutama bagi daerah yang kaya akan sumber daya alam. Beberapa daerah belum sepenuhnya lepas dari bayang-bayang Jakarta dan tidak dapat menikmati secara leluasa kekayaan alamnya. Tuntutan otonomi khusus diharapkan mampu menjawab permasalahan pelik yang dihadapi tanpa mendatangkan pertanyaan-pertanyaan lain Indonesia, Yogyakarta, 2017, hlm 10 
yang justru akan memperunyam dilema yang sudah ada.

Sebagai bahan pelajaran, status otonomi khusus yang kini dikecap Aceh dan Papua merupakan hasil dari perjuangan panjang dan berdarah-darah. Kedua daerah tersebut dalam mendapat hak otonomi khusus didasarkan pada perjuangan historis dan kultural masyarakatnya selain kekayaan alam yang mereka miliki. Disamping itu apabila kita berkaca pada penetapan otsus kedua daerah tersebut, faktor suhu politik di daerah dan gerakan pemberontakan disana juga menjadi salah satu penyebab kedua daerah tersebut akhirnya mengecap status otsus. Dengan dalih untuk memperkuat integritas bangsa, pemberian status otsus terkesan bernuansa politis dan sarat kepentingan politis dari pemerintah pusat baik secara langsung maupun tidak langsung. Hal ini diperkuat dengan kenyataan bahwasanya dari dulu hingga sekarang, tidak adanya satupun ketentuan yang mengatur secara khusus mengenai indikator dan parameter sebuah penetapan dan pengakuan satuan daerah-daerah yang bersifat khusus sebagaimana yang dimaksud oleh UUD 1945.

\section{Penutup}

\section{Kesimpulan}

Berdasarkan hasil uraian di atas, maka dapat Penulis ambil kesimpulan dari makalah ini adalah sebagai berikut.

Pertama, bahwa otonomi daerah yang sudah terlaksana di Indonesia sebagai salah satu tuntutan dari reformasi belum dirasakan sepenuhnya dapat menjawab keluhan dan tuntutan banyak daerah di Indonesia. Disamping pembangunan yang masih terlalu berpusat di Jawa, keluhan mengenai ketidakadilan pembagian hasil sumber daya alam antara pemerintah pusat dan daerah masih terdengar nyaring.

Kedua, pemerintah pusat masih terkesan berhasrat untuk menguasai daerah dan tidak sepenuhnya menjalankan otonomi daerah seluas-luasnya, sebagaimana tercermin dalam pengetatan peraturan pelaksana berupa ketentuan yang 
menyulitkan daerah dalam UU Otonomi

Daerah dan UU Perimbangan Keuangan Pusat dan Daerah.

Ketiga, bahwa tuntutan desentralisasi asimetris (otonomi khusus) sudah tidak dapat dihindarkan lagi menjadi salah satu solusi bagi daerah yang merasa tidak diperlakukan adil oleh pemerintah pusat untuk mencapai peningkatan pembangunan dan kesejahteraan sebagaimana yang diinginkan oleh daerah.

\section{Saran}

Kemudian Penulis dapat merumuskan saran yang kemudian diharapkan dapat bermanfaat sebagai berikut.

Pertama, agar dilakukan evaluasi menyeluruh terhadap regulasi dan praktik pelaksanaan otonomi daerah di Indonesia agar sejalan dengan Asas Desentralisasi. Hal ini dapat dimulai dengan melakukan amandemen dan revisi terhadap UUD NRI 1945 serta peraturan perundang-undangan dibawahnya, agar senada dengan semangat otonomi daerah yang seluas-luasnya.
Kedua, agar dievaluasi kembali mekanisme pembagian hasil daerah dari pusat, dengan melahirkan Undang-Undang Perimbangan Keuangan Pusat dan Daerah yang sejalan dengan Asas Desentralisasi. Yang mana sebagaimana yang diketahui, saat ini kita masih menganut mekanisme subsidi silang. Artinya adalah, daerah yang mengalami pendapatan minus akan disubsidi oleh daerah yang berpendapatan lebih. Mekanisme ini yang kemudian membuat daerah yang memiliki potensi lebih baik dari sumber daya alam maupun lainnya tidak dapat menikmati seutuhnya kekayaan yang dimiliki.

\section{Daftar Pustaka}

\section{Buku-buku}

Jimly Asshiddiqie, Konstitusi dan Konstitualisme Indonesia, Sinar Grafika, Jakarta, 2011

Moh. Mahfud MD, Konstitusi dan Hukum dalam Kontroversi Isu, Jakarta, Rajawali Press, 2012

Soehino, Ilmu Negara, Yogyakarta, Liberti, 2005 
Ni'matul Huda, Desentralisasi Asimetris Dalam NKRI Kajian Terhadap Daerah Istimewa, Daerah Khusus dan Otonomi Khusus, Nusa Media, Bandung, 2014 Otonomi Daerah, Pustaka Pelajar, Yogyakarta, 2015

\section{Jurnal}

Indra Fatwa, Gagasan Kawasan Ekonomi Khusus Dumai Berbasis Industri Hilir Kelapa Sawit, Universitas Islam Indonesia, Yogyakarta, 2017. Indra Fatwa, Putusan Mahkamah Konstitusi Yang Bersifat Mengatur (Positive Legislature) Dalam Upaya Menghadirkan Keadilan Substantif, Jurnal Equitable, Volume 5, Nomor. 2, 2020

Wasisto Raharjo Jati, Inkonsistensi Paradigma Otonomi Daerah di Indonesia: Dilema Sentralisasi atau Desentralisasi, Jurnal Konstitusi, Volume 9, Nomor 4, Desember 2012

\section{Data Elektronik}

http://kompasiana.com/joniwr/hut-riau-ke54-dilema-otonomi-bagi-propinsikaya Diakses pada tanggal 15 Agustus 2016, Pukul 20:30 